\title{
Inhibition of enzymes by Atebrin
}

Citation for published version (APA):

Hemker, H. C., \& Hülsmann, W. C. (1960). Inhibition of enzymes by Atebrin. Biochimica et Biophysica Acta. Mucoproteins and Mucopolysaccharides, 44, 175-177. https://doi.org/10.1016/0006-3002(60)915407

Document status and date:

Published: 01/01/1960

DOI:

10.1016/0006-3002(60)91540-7

Document Version:

Version created as part of publication process; publisher's layout

\section{Please check the document version of this publication:}

- A submitted manuscript is the version of the article upon submission and before peer-review. There can be important differences between the submitted version and the official published version of record.

People interested in the research are advised to contact the author for the final version of the publication, or visit the DOI to the publisher's website.

- The final author version and the galley proof are versions of the publication after peer review.

- The final published version features the final layout of the paper including the volume, issue and page numbers.

Link to publication

\footnotetext{
General rights rights.

- You may freely distribute the URL identifying the publication in the public portal. please follow below link for the End User Agreement:

www.umlib.nl/taverne-license

Take down policy

If you believe that this document breaches copyright please contact us at:

repository@maastrichtuniversity.nl

providing details and we will investigate your claim.
}

Copyright and moral rights for the publications made accessible in the public portal are retained by the authors and/or other copyright owners and it is a condition of accessing publications that users recognise and abide by the legal requirements associated with these

- Users may download and print one copy of any publication from the public portal for the purpose of private study or research.

- You may not further distribute the material or use it for any profit-making activity or commercial gain

If the publication is distributed under the terms of Article $25 \mathrm{fa}$ of the Dutch Copyright Act, indicated by the "Taverne" license above, 
Reprinted from Biochim. Biophys. Acta, Vol. 44 (1960)

\section{Inhibition of enzymes by Atebrin}

Inhibition of an enzymic reaction by Atebrin is frequently interpreted in the biochemical literature as a proof that a flavoprotein is involved in the reaction, especially when the inhibition is reversed by FMN or FAD. It is assumed that the drug competes with the flavin for the apo-enzyme.

It is the purpose of the present communication to draw attention to the fact,

Abbreviations: FMN, flavin mononucleotide; FAD, flavin-adenine dinucleotide; TPN, TPNH, oxidized and reduced triphosphopyridine nucleotide; Tris, tris(hydroxymethyl)aminomethane. 
which has already been pointed out by others ${ }^{1,2}$, that Atebrin is not a specific inhibitor of flavoproteins. It is shown that reversal of inhibition by FMN is not due to competition between the flavine and Atebrin for the enzyme, but is due to the formation of a compound between the Atebrin and the FMN.

Erythrocyte glucose 6-phosphate dehydrogenase and liver esterase, which are almost certainly not flavoproteins, were found to be inhibited by Atebrin.

Glucose 6-phosphate dehydrogenase activity could not be measured in the usual way, by following directly the reduction of TPN at $340 \mathrm{~m} \mu$, since Atebrin absorbs strongly at this wavelength. This difficulty was overcome by precipitating the Atebrin at various times by adding $\mathrm{NaOH}$ to $\mathrm{pH}$ Io. The absorbancy at $340 \mathrm{~m} \mu$ was then measured on the clear supernatant. Recovery tests showed that no loss of TPNH occurred in this procedure. Fig. I shows that $5 \mathrm{~m} M$ Atebrin caused considerable inhibition of this enzyme.

Ali-esterase was studied either as a rat-liver microsomal preparation (fraction between $\mathrm{I}_{5}, 000 \times \mathrm{g}$ for $\mathrm{IO} \mathrm{min}$ and $\mathrm{I05,000} \times \mathrm{g}$ for $60 \mathrm{~min}$ ), or as a soluble preparation obtained by treating an acetone powder of the microsomal pellets with butanol, followed by extraction of the powder with $0.25 M$ Tris-HCl buffer, $\mathrm{pH} 7.75$ ( $c f$. ref. 3). The enzyme activity was determined manometrically in $\mathrm{NaHCO}_{3}-\mathrm{H}_{2} \mathrm{CO}_{3}$ buffer. The degree of inhibition of the enzyme in microsomes at various concentrations of Atebrin is shown in Fig. 2. $50 \%$ inhibition was obtained with $5 \mathrm{~m} M$ Atebrin, which is similar to the concentration giving $50 \%$ inhibition of succinic oxidase in Löw's experiments ${ }^{4}$. The soluble ali-esterase was also inhibited to the same extent.

The ali-esterase was not inhibited by $2 \mu \mathrm{g} / \mathrm{ml}$ antimycin, $4 \mathrm{~m} M$ 2,4-dinitrophenol, $5 \mathrm{~m} M$ aureomycin, $5 \mathrm{~m} M$ chloropromazine, or $5 \mathrm{~m} M$ methylene blue. Chloramphenicol $(5 \mathrm{~m} M)$ was slightly inhibitory. Pentachlorophenol inhibited quite strongly $(50 \%$ inhibition by $1.3 \mathrm{~m} M$, $100 \%$ by $5.2 \mathrm{mM})$.

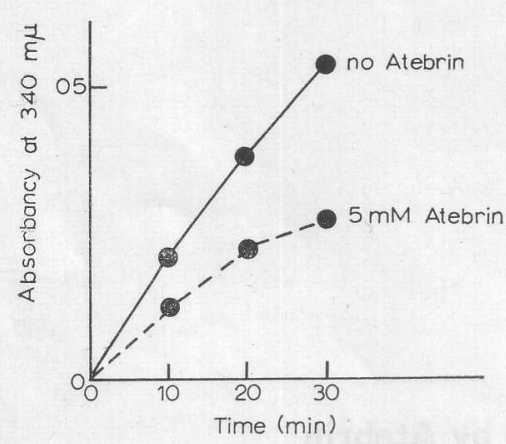

Fig. I. Inhibition of glucose 6-phosphate dehydrogenase by Atebrin. Each reaction vessel contained: $0.05 M$ Tris- $\mathrm{HCl}$ buffer, $\mathrm{pH}$ 7.75, $0.02 M \mathrm{MgCl}_{2}$, 0.015 $M$ glucose 6-phosphate, $0.0002 M$ TPN, $0.2 \mathrm{ml}$ glucose 6-phosphate dehydrogenase preparation, $0.005 M$ Atebrin (when present), water to a final volume of $2.5 \mathrm{ml}$. The reaction was stopped by adding $\mathrm{NaOH}$ to $\mathrm{pH}$ ro and subsequent boiling. The absorbancy found in a zero-time control was subtracted from the experimental values.

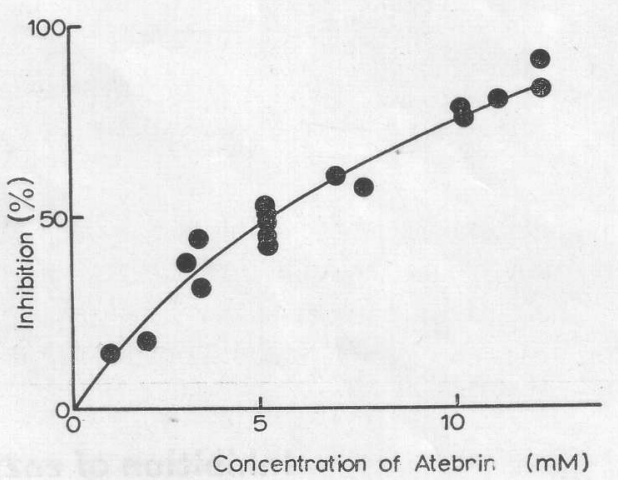

Fig. 2. Inhibition of aliesterase, microsomebound or soluble, by Atebrin. The activity was measured in Warburg manometers, each vessel containing in the main compartment: o.I $\mathrm{ml}$ enzyme preparation, varying amounts of Atebrin, $0.025 M \mathrm{NaHCO}_{3}$, water to a final volume of $2.9 \mathrm{ml}$. After temperature equilibration, the substrate, 0.I $\mathrm{ml} \mathrm{I0} \%$ tributyrin, was tipped in from the side arm. Gas phase $\mathrm{N}_{2}-\mathrm{CO}_{2}(95: 5)$. 
The inhibition of the microsome-bound ali-esterase by Atebrin or pentachlorophenol was fully reversed by sedimenting the microsomes and washing with $0.5 \%$ bovine serum albumin, $\mathrm{pH} 7.3$ or $\mathrm{NaHCO}_{3}-\mathrm{H}_{2} \mathrm{CO}_{3}$ buffer, $\mathrm{pH} 7.4$.

TABLE I

REVERSAL BY FMN OF ATEBRIN INHIBITION OF ALIESTERASE

\begin{tabular}{lrrrr}
\hline Atebrin $(\mathrm{m} M)$ & 5 & 0 & 5 & 5 \\
FMN $(\mathrm{m} M)$ & 0 & 5 & 5 & 10 \\
Inhibition $(\%)$ & 55 & 0 & 37 & 24 \\
\hline
\end{tabular}

Table I shows that inhibition by Atebrin was partly reversed by FMN. During the course of these experiments it was observed that FMN and Atebrin, both of which are yellow, reacted together to form a red-coloured complex. The difference spectrum of the complex is shown in Fig. 3. YAGI ${ }^{5}$ has shown that chloropromazine, which is chemically related to Atebrine, as well as other aromatic compounds, forms a complex with flavins.

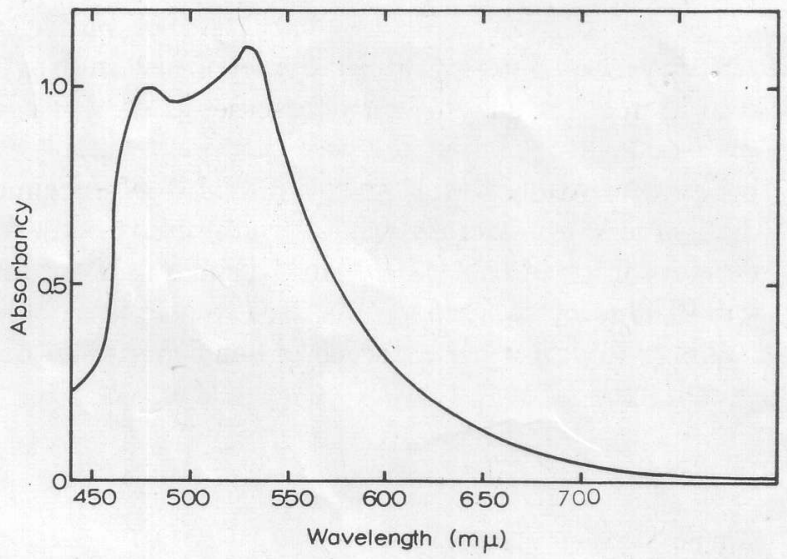

Fig. 3. Difference spectrum: ( $5 \mathrm{~m} M$ Atebrin $+5 \mathrm{~m} M$ FMN) minus $5 \mathrm{~m} M$ Atebrin minus $5 \mathrm{~m} M$ FMN, in Tris- $\mathrm{HCl}$ buffer, $\mathrm{pH} 7 \cdot 75$.

These experiments strongly support HeLlerman's view ${ }^{1}$ that Atebrin is a relatively non-specific enzyme inhibitor, acting by binding with proteins in general.

The authors wish to thank Prof. E. C. Slater for helpful criticism and advice.

This investigation was supported in part by research grant 6569 from the U.S. Public Health Service.

$\begin{array}{cl}\text { Department of Physiological Chemistry, University of Amsterdam, } & \text { H. C. Hemker } \\ \text { Amsterdam (Netherlands) } & \text { W. C. HülsmanN }\end{array}$

1 L. Hellerman, A. Lindsay and M. R. Bovarnich, J. Biol. Chem., i63 (I946) 553.

2 T. S. WORK AND E. WORK, The basis of chemotherapy, Edinburgh and London: Oliver and Boyd, Ltd., I948, pp. I65, I8I.

${ }^{3}$ R. K. Morton, in S. P. Colowick and N. O. Kaplan, Methods in Enzymology, Vol. I, New

York, Academic Press, Inc., I955, p. 40.

${ }^{4}$ H. Löw, Biochim. Biophys. Acta, 32 (I959) I.

5 K. Yagi, T. Ozawa and T. Nagatzu, Nature, I84 (1959) 982.

Received July 2nd, I960 